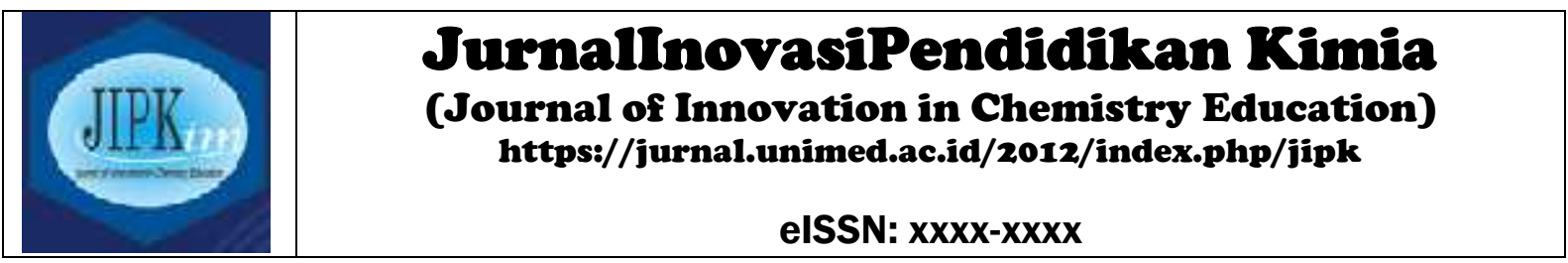

\title{
Analisis PBL Menggunakan Animasi dan Peta Konsep Melalui KBK Dalam Meningkatkan Hasil Belajar Mahasiswa
}

\author{
Freddy Tua Musa Panggabean ${ }^{\mathrm{a} *}$, Ani Sutiani ${ }^{\mathrm{a}}$ dan Jamalum Purba ${ }^{\mathrm{a}}$ \\ ${ }^{a}$ Jurusan Kimia, FMIPA,Universitas Negeri Medan \\ *Alamat Korespondensi: freddypanggabean@unimed.ac.id
}

\begin{abstract}
Abstrak:
Salah satu materi pokok dalam mata kuliah Kimia Umum-II yang memiliki kajian yang cukup luas, sarat dengan konsep dan bersifat abstrak adalah kelarutan/hasil kali kelarutan. Materi pokok tersebut akan lebih tepat diajarkan dengan PBL menggunakan animasi maupun peta konsep sehingga mahasiswa mudah memahmi dan menjadikan perkuliahan lebih bermakna. Selain itu, faktor lain yang juga berpengaruh terhadap pencapaian hasil belajar mahasiswa adalah kemampuan berpikir kritis (KBK) mahasiswa. Hasil penelitian disimpulkan bahwa: 1) terdapat pengaruh yang signifikan penerapan PBL menggunakan animasi terhadap hasil belajar kimia mahasiswa yaitu rata-rata hasil belajar kimia mahasiswa yang diajarkan dengan PBL menggunakan animasi lebih tinggi dibandingkan hasil belajar mahasiswa yang diajarkan dengan model PBL menggunakan peta konsep; 2) terdapat pengaruh yang signifikan KBK mahasiswa terhadap hasil belajar kimia mahasiswa yaitu rata-rata hasil belajar kimia mahasiswa yang memiliki KBK tinggi lebih baik atau lebih tinggi dibandingkan hasil belajar kimia mahasiswa yang memiliki KBK rendah; 3) tidak terdapat pengaruh yang signifikan interaksi antara penerapan PBL menggunakan animasi maupun peta konsep ditinjau dari KBK mahasiswa terhadap hasil belajar kimia yang dicapai mahasiswa.
\end{abstract}

Kata kunci:

PBL, Animasi, Peta Konsep, KBK, Hasil Belajar

\section{PENDAHULUAN}

Mata kuliah Kimia Umum-II merupakan mata kuliah yang sarat dengan konsep, mulai dari konsep sederhana sampai konsep yang lebih kompleks dan abstrak, sehingga sangat diperlukan pemahaman yang benar terhadap konsep dasar yang membangun konsep tersebut. Salah satu materi pokok yang sarat dengan konsep adalah materi kelarutan/hasil kali kelarutan. Pokok bahasan tersebut merupakan materi yang terkesan mudah dan sederhana, namun memiliki kajian yang cukup luas, terutama setelah diaplikasikan dalam mengatasi permasalahan perhitungan kimia.
Melalui pengalaman peneliti dalam mengajarkan mata kuliah Kimia Umum-II ditemukan beberapa permasalahan khususnya berkaitan dengan pembelajaran kelarutan/hasil kali kelarutan, antara lain: (1) mahasiswa masih cenderung sulit menguasai konsep dan materi kelarutan/hasil kali kelarutan; (2) mahasiswa mengalami kesulitan dalam menghubungkan konsepkonsep materi yang saling terkait khususnya materi pokok kelarutan/hasil kali kelarutan; (3) kurangnya motivasi atau usaha belajar mahasiswa dalam mengikuti perkuliahan kimia umum-II yang dapat dilihat dari tugastugas yang diberikan dosen masih belum dikerjakan dengan baik; dan (4) masih 
rendahnya hasil belajar yang dicapai mahasiswa pada materi pokok kelarutan/hasil kali kelarutan.

\section{Problem Based Learning}

Program inovatif Problem Based Learning (PBL) pertama kali diperkenalkan oleh Faculty of Health Sciences of McMaster University di Kanada pada tahun 1966 yang menjadi ciri khas pelaksanaan PBL di Mc.Master adalah filosofi pendidikan yang berorientasi pada masyarakat, terfokus pada manusia, melalui pendekataan antar ilmu cabang ilmu pengetahuan dan belajar berdasarkan masalah. Dalam perkembangannya, PBL telah diadopsi baik secara keseluruhan atau sebagian oleh banyak lembaga pendidikan di dunia.

Bound dan Felleti dalam Jauhari (2011), menjelaskan bahwa Problem based learning adalah suatu pendekatan untuk membelajarkan siswa untuk mengembangkan keterampilan berpikir dan keterampilan memecahkan masalah, belajar peranan orang dewasa yang otentik serta menjadi pelajar mandiri. Duch dalam Riyanto (2010), menyatakan bahwa PBL adalah suatu model pembelajaran yang menghadapkan peserta didik pada tantangan belajar untuk belajar. Siswa atau mahasiswa aktif bekerjasama di dalam kelompok untuk mencari solusi permasalahan dunia nyata.

Inti model pembelajaran PBL berupa menyuguhkan situasi bermasalah yang autentik (benar atau nyata) dan bermakna kepada siswa. Permasalah ini sebagai acuan bagi siswa untuk merumuskan, menganalisis, dan memecahkannya. Menurut Sanjaya (2009), model PBL dapat diartikan sebagai rangkaian aktivitas pembelajaran yang menekankan kepada proses penyelesaian masalah yang dihadapi secara ilmiah.

\section{Media Animasi}

Hasil penelitian Hasrul (2011), menyimpulkan bahwa mahasiswa memiliki pandangan positif terhadap media pembelajaran animasi berbasis Adobe Flash CS3 dengan kategori baik dan sangat baik. Iriani, $d k k$ (2009), menyimpulkan: 1) terdapat perbedaan hasil belajar yang signifikan antara pembelajaran yang menggunakan animasi 3D dan pembelajaran dengan OHP, dan 2) sebagian besar siswa memberikan respon positif terhadap penggunaan animasi 3D dalam pembelajaran struktur atom. Penelitian Butar-butar (2007), menyimpulkan bahwa siswa yang diajarkan dengan program animasi komputer mendapat hasil belajar lebih tinggi dibandingkan siswa yang diajar tanpa menggunakan program animasi komputer. Dengan kehadiran media, proses pembelajaran yang dialami siswa maupun mahasiswa diharapkan lebih bermakna, menyenangkan dan materi-materi yang dipelajari juga akan mudah diingat.

\section{Peta Konsep}

Peta konsep atau pemetaan konsep adalah alat peraga untuk memperlihatkan hubungan antara beberapa konsep. Hubungan antar konsep dapat dirinci dalam bentuk pernyataan-pernyataan. Dahar (2011), mengemukkan bahwa peta konsep digunakan untuk menyatakan hubungan yang bermakna antara konsep-konsep dalam bentuk proposisi-proposisi. Proposisi-proposisi merupakan dua atau lebih konsep-konsep yang dihubungkan oleh kata-kata dalam suatu unit semantik. Dalam bentuknya yang paling sederhana, suatu peta konsep hanya terdiri atas dua konsep yang dihubungkan oleh satu kata penghubung untuk membentuk suatu proposisi.

Martin dalam Trianto (2011), menjelaskan bahwa peta konsep adalah ilustrasi grafis konkret yang mengidikasikan bagaimana 
sebuah konsep tunggal dihubungkan ke konsep-konsep lain pada kategori yang sama. Asan (2007), mengemukakan bahwa peta konsep merupakan representasi dari beberapa konsep serta berbagai hubungan antar struktur pengetahuan yang dimiliki oleh seseorang. Novak (2010), menyatakan bahwa peta konsep dapat membantu siswa belajar tentang bagaimana cara belajar yang baik dan juga membantu dalam menyerap pengetahuan dan menafsirkan kreativitas di semua bidang ilmu. Situmorang, $d k k$, (2000), dalam Jati, $d k k$, (2015), melaporkan bahwa peta konsep merupakan media pendidikan yang dapat menunjukkan konsep ilmu yang sistematis.

Menurut Akeju, $d k k$, (2012), media peta konsep berkontribusi pada peningkatan hasil belajar siswa bidang studi fisika. Hasil penelitian Sakiyo dan Waziri (2015), melaporkan bahwa siswa biologi yang diajarkan materi konsep biologi menggunakan metode concept mapping mewujudkan hasil belajar yang lebih baik dibandingkan siswa yang diajarkan dengan metode ceramah.

Simatupang dan Dewi (2014), mengatakan dengan bantuan media peta konsep sebanyak $87 \%$ mahasiswa mampu menyelesaikan mata kuliah kimia anorganikI. Hasil penelitian Silaban (2013), media peta konsep sangat efektif dalam meningkatkan prestasi belajar mahasiswa dalam mengikuti mata kuliah biokimia dasar. Elvinawati (2011), menyimpulkan bahwa penerapan kontruktivisme dan model peta konsep dapat meningkatkan aktivitas dan hasil belajar mahasiswa pada mata kuliah kimia pemisahan. Hasil penelitian Hayaton (2014), menyimpulkan bahwa model pembelajaran peta konsep dapat meningkatkan aktivitas dan hasil belajar siswa.

Pembuatan peta konsep dilakukan dengan membuat suatu sajian visual atau suatu diagram tentang bagaimana ide-ide penting atau suatu topik tertentu dihubungkan satu sama lain. Posner dan Rudnitsky dalam Trianto (2011), menulis bahwa peta konsep mirip peta jalan, namun peta konsep menaruh perhatian pada hubungan antara ide-ide, bukan hubungan antar tempat. Untuk membuat suatu peta konsep, siswa dilatih untuk mengidentifikasi ide-ide kunci yang berhubungan dengan suatu topik dan menyusun ide-ide tersebut dalam suatu pola logis.

\section{Kemampuan Berpikir Kritis}

Menurut Costa dalam Liliasari (2009), ada 4 pola berpikir tingkat tinggi, yaitu: (1) berpikir kritis, (2) berpikir kreatif, (3) pemecahan masalah, dan (4) pengambilan keputusan. Di antara empat pola berpikir tingkat tinggi tersebut, berpikir kritis mendasari tiga pola berpikir yang lain. Artinya berpikir kritis perlu dikuasai lebih dahulu sebelum ketiga pola berpikir tingkat tinggi yang lain. Menurut Syah (2009), berpikir rasional dan kritis adalah perwujudan perilaku belajar terutama yang bertalian dengan pemecahan masalah. Dalam berpikir kritis mahasiswa dituntut menggunakan strategi kognitif tertentu yang tepat untuk menguji keandalan gagasan pemecahan masalah dan mengatasi kesalahan atau kekurangan.

\section{METODE}

Penelitian ini menggunakan metode Experimental untuk menguji pengaruh utama dan pengaruh interaksi penerapan model PBL menggunakan animasi dan peta konsep terhadap hasil belajar mahasiswa ditinjau dari KBK mahasiswa. Penelitian ini melibatkan dua variabel bebas (pembelajaran PBL menggunakan animasi dan peta konsep), dua variabel moderator (KBK tinggi dan rendah) dan satu variabel terikat (hasil belajar kimia mahasiswa). Instrumen yang digunakan adalah tes hasil belajar pada maateri pokok kelarutan/hasil kali kelarutan dan tes KBK 
mahasiswa. Teknik analisis data yang digunakan adalah ANAVA dua jalur pada taraf signifikan $\alpha=0,05$. Analisis data dilakukan dengan bantuan program SPSS 16.0 .

\section{HASIL PENELITIAN}

\section{Deskripsi Data Hasil Belajar Kimia Mahasiswa}

Data hasil belajar mahasiswa dikelompok berdasarkan interaksi antara kelas dengan KBK mahasiswa. Perbandingan kelompok data hasil belajar mahasiswa berdasarkan temuan penelitian dirangkum pada Tabel 1.

Tabel 1. Perbandingan Hasil Belajar Kimia Mahasiswa Berdasarkan Kelas dan KBK Mahasiswa

\begin{tabular}{|c|c|c|c|}
\hline \multicolumn{4}{|c|}{ Kelas } \\
\hline KBK & $\begin{array}{c}\text { PBL dengan } \\
\text { Animasi } \\
\text { (A1) }\end{array}$ & $\begin{array}{c}\text { PBL dengan } \\
\text { Peta Konsep } \\
\text { (A2) }\end{array}$ & Total \\
\hline $\begin{array}{c}\text { Tinggi } \\
\text { (B1) }\end{array}$ & $\begin{array}{c}24,05 \pm 2,09 \\
(\mathrm{~N}=19)\end{array}$ & $\begin{array}{c}22,45 \pm 2,02 \\
(\mathrm{~N}=22)\end{array}$ & $\begin{array}{c}23,20 \pm \\
2,22 \\
(\mathrm{~N}=41)\end{array}$ \\
\hline $\begin{array}{l}\text { Rendah } \\
\text { (B2) }\end{array}$ & $\begin{array}{c}22,55 \pm 2,24 \\
(N=20)\end{array}$ & $\begin{array}{c}19,06 \pm 3,51 \\
(\mathrm{~N}=17)\end{array}$ & $\begin{array}{c}20,95 \pm \\
3,35 \\
(\mathrm{~N}=37)\end{array}$ \\
\hline Total & $\begin{array}{c}23,28 \pm 2,27 \\
(\mathrm{~N}=39)\end{array}$ & $\begin{array}{c}20,97 \pm 3,22 \\
(\mathrm{~N}=39)\end{array}$ & \\
\hline
\end{tabular}

Dari data pada Tabel 1 di atas, mahasiswa yang diajarkan dengan PBL menggunakan animasi $(23,28 \pm 2,27)$ sedangkan dengan PBL menggunakan peta konsep $(20,97 \pm$ 3,22). Selanjutnya hasil belajar mahasiswa yang memiliki KBK tinggi $(23,20 \pm 2,22)$ sedangkan yang memiliki KBK rendah $(20,95 \pm 3,35)$.

Lebih lanjut hasil belajar mahasiswa berdasarkan interaksi antara kelas dan KBK menunjukkan bahwa hasil belajar kelompok mahasiswa yang diajarkan dengan PBL menggunakan animasi dan memiliki KBK tinggi $(24,05 \pm 2,09)$ lebih tinggi dibandingkan dengan PBL mengunakan animasi dan memiliki KBK rendah $(22,55 \pm$ 2,24); hasil belajar kelompok mahasiswa yang diajarkan PBL menggunakan peta konsep dan memiliki KBK tinggi $(22,45 \pm$
2,02) lebih tinggi dibandingkan dengan PBL menggunakan peta konsep dan memiliki KBK rendah $(19,06 \pm 3,51)$.

\section{Hasil Uji Normalitas Data}

Normalitas data hasil belajar kedua kelompok sampel diuji menggunakan uji Chi Kuadrat atau menggunakan teknik Kolmogorov-Smirnov Test.

Tabel 2. Hasil Uji Normalitas Data

One-Sample Kolmogorov-Smirnov Test

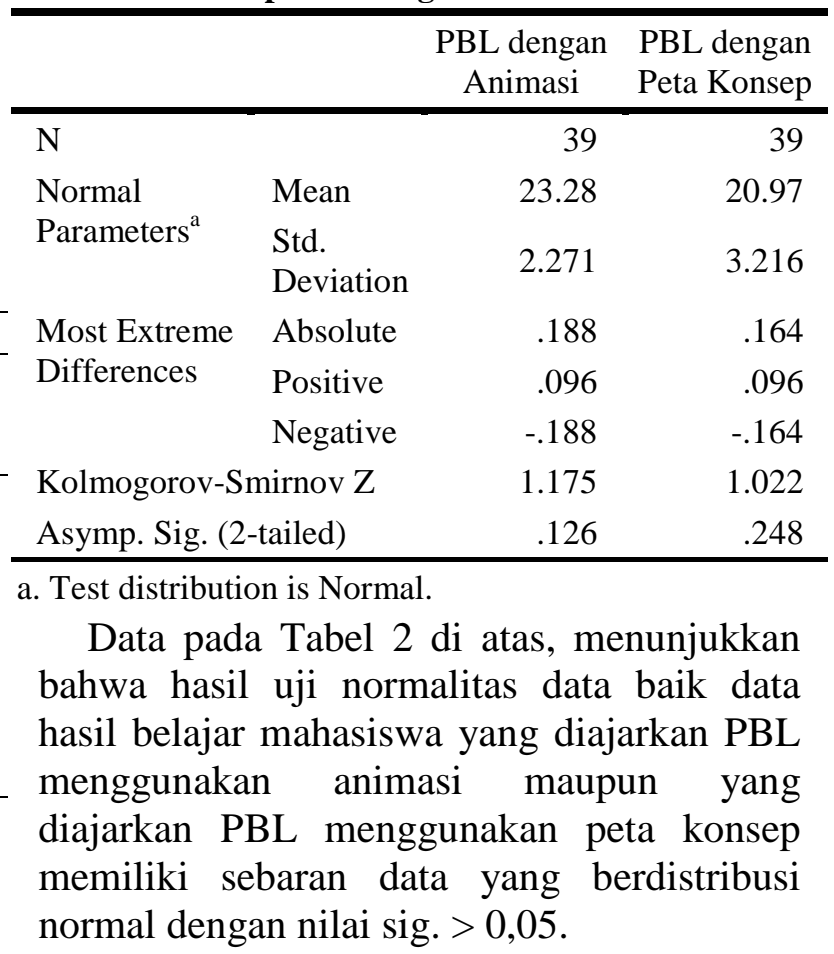

\section{Hasil Uji Homogenitas Data}

Pengujian homogenitas data diuji dengan teknik Levene's Test atau Uji F menggunakan program SPSS 16.0. Data dinyatakan memiliki varians yang sama (homogen) jika nilai sig. > 0,05.

Tabel 3. Hasil Uji Homogenitas Data

Levene's Test of Equality of Error Variance.

Dependent Variable:Hasil Belajar

\begin{tabular}{|c|c|c|c|}
\hline $\mathrm{F}$ & df1 & df2 & Sig. \\
\hline 2.042 & 3 & 74 & .115 \\
\hline $\begin{array}{l}\text { Tests the nu } \\
\text { variance of } \\
\text { across grou }\end{array}$ & $\begin{array}{l}\text { poth } \\
\text { depen }\end{array}$ & $\begin{array}{l}\text { that the } \\
\text { t varial }\end{array}$ & $\begin{array}{l}\text { or } \\
\text { s equal }\end{array}$ \\
\hline
\end{tabular}


Berdasarkan data pada Tabel 3, dapat dijelaskan bahwa hasil perhitungan homogenitas data disimpulkan bahwa varians kedua kelas yang dijadikan sampel penelitian dinyatakan homogen (sama) dengan nilai sig. $>0,05$.

\section{Pengujian Hipotesis}

Pengujian hipotesis dianalisis menggunakan teknik analisis varian dua jalur (two way anova) dengan bantuan program SPSS 16.0.

Tabel 4. Hasil Analisis Varians Dua Jalur

Tests of Between-Subjects Effects

Dependent Variable:Hasil

Belajar

\begin{tabular}{lrrrrr}
\hline Source & $\begin{array}{c}\text { Type III Sum } \\
\text { of Squares }\end{array}$ & Df & $\begin{array}{c}\text { Mean } \\
\text { Square }\end{array}$ & F & Sig. \\
\hline Corrected & $236.425^{\mathrm{a}}$ & 3 & 78.808 & 12.781 & .00 \\
Model & & & & & \\
Intercept & 37525.700 & 1 & 37525.70 & 6085.7 & .00 \\
KLS & 125.178 & 1 & 125.178 & 20.301 & .00 \\
KBK & 115.963 & 1 & 115.963 & 18.806 & .00 \\
KLS * KBK & 17.321 & 1 & 17.321 & 2.809 & .09 \\
Error & 456.293 & 74 & 6.166 & & \\
Total & 38886.000 & 78 & & & \\
Corrected & 692.718 & 77 & & & \\
Total & & & & & \\
\hline
\end{tabular}

a. R Squared $=.341$ (Adjusted R Squared $=.315$ )

Berdasarkan hasil pengujian hipotesis pada Tabel 4 di atas, diperoleh beberapa kesimpulan sebagai berikut: (1) Pada kolom KLS (kelas) diperoleh nilai F sebesar 20,301 dan nilai sig. 0,000. Karena nilai sig. 0,000 < 0,05 maka $\mathrm{H}_{\mathrm{a}}$ diterima atau $\mathrm{H}_{\mathrm{o}}$ ditolak yang berarti hipotesis pertama diterima dan teruji kebenarannya pada taraf $\alpha=0,05$; (2) Pada melihat kolom KBK (kemampuan berpikir kritis) diperoleh nilai $\mathrm{F}$ sebesar 18,806 dan nilai sig. 0,000. Karena nilai sig. 0,000 < 0,05 maka $\mathrm{H}_{\mathrm{a}}$ diterima atau $\mathrm{H}_{\mathrm{o}}$ ditolak yang berarti hipotesis kedua diterima dan teruji kebenarannya pada taraf $\alpha=0,05$; (3) Pada kolom interaksi $\mathrm{KLS} * \mathrm{KBK}$ diperoleh nilai $\mathrm{F}$ sebesar 2,809 dan nilai sig. 0,098. Karena nilai sig. 0,098>0,05 maka $\mathrm{H}_{\mathrm{a}}$ ditolak atau $\mathrm{H}_{\mathrm{o}}$ diterima yang berarti hipotesis ketiga ditolak dan tidak teruji kebenarannya pada taraf $\alpha=0,05$.

\section{HASIL DAN PEMBAHASAN}

Hasil temuan penelitian dan pengujian hipotesis menunjukkan bahwa nilai rata-rata hasil belajar kimia mahasiswa kelas eksperimen A yang diajarkan dengan PBL menggunakan animasi $(23,28 \pm 2,27)$ lebih tinggi dibandingkan hasil belajar mahasiswa kelas ekperimen B yang diajarkan dengan PBL menggunakan peta konsep (20,97 \pm 3,22). Hasil ini memberi indikasi bahwa penerapan PBL menggunakan animasi lebih efektif atau memberikan pengaruh yang positif terhadap hasil belajar kimia mahasiswa dibandingkan penerapan PBL menggunakan peta konsep. Hal ini juga dibuktikan dari hasil pengujian hipotesis dengan nilai $F$ sebesar 20,301 dan nilai signifikansi sebesar 0,000 atau lebih kecil dari nilai signifikansi yang diharapkan yaitu 0,05 .

Hasil analisis dan pengujian hipotesis juga menunjukkan bahwa rata-rata hasil belajar kimia kelompok mahasiswa yang memiliki KBK tinggi $(23,20 \pm 2,22)$ lebih tinggi dibandingkan kelompok mahasiswa yang memiliki KBK rendah $(20,95 \pm 3,35)$. Hasil ini memberi indikasi bahwa faktor KBK mahasiswa juga turut mempengaruhi hasil yang dicapai mahasiswa dalam belajar atau dengan kata lain KBK mahasiswa memberikan pengaruh positif terhadap pencapaian hasil belajar mahasiswa. Hal ini juga dibuktikan dari hasil pengujian hipotesis dengan nilai $\mathrm{F}$ sebesar 18,806 dan nilai signifikansi sebesar 0,000 atau lebih kecil dari nilai signifikansi yang diharapkan yaitu 0,05 .

Lebih lanjut hasil analisis dan pengujian hipotesis disimpulkan bahwa tidak terdapat pengaruh interaksi antara penerapan model PBL dengan animasi maupun peta konsep terhadap hasil belajar kimia mahasiswa ditinjau dari KBK mahasiswa. Hal ini dapat dibuktikan dari hasil pengujian hipotesis dengan nilai $F$ sebesar 2,809 dan nilai 
signifikansi sebesar 0,098 atau lebih besar dari nilai signifikansi yang diharapkan yaitu 0,05 . Tidak adanya pengaruh interaksi antara penerapan model PBL dengan animasi maupun peta konsep terhadap hasil belajar kimia mahasiswa ditinjau dari KBK mahasiswa memberi indikasi bahwa mahasiswa yang memiliki KBK tinggi jika diajarkan dengan model PBL menggunakan peta konsep belum tentu atau tidak berarti lebih baik dibandingkan mahasiswa yang memiliki KBK rendah jika diajarkan dengan PBL menggunakan animasi.

\section{KESIMPULAN}

Berdasarkan hasil analisis dan pengujian hipotesis, maka dapat diambil beberapa simpulan sebagai berikut:

1. Terdapat pengaruh yang signifikan penerapan PBL menggunakan animasi terhadap hasil belajar kimia mahasiswa pada materi pokok kelarutan/hasil kali kelarutan dibandingkan penerapan PBL menggunakan peta konsep. Rata-rata hasil belajar kimia mahasiswa yang diajarkan dengan PBL menggunakan animasi lebih tinggi dibandingkan hasil belajar mahasiswa yang diajarkan dengan PBL menggunakan peta konsep.

2. Terdapat pengaruh yang signifikan KBK mahasiswa terhadap hasil belajar kimia mahasiswa pada materi pokok kelarutan/hasil kali kelarutan. Rata-rata hasil belajar kimia mahasiswa yang memiliki KBK tinggi lebih baik atau lebih tinggi dibandingkan hasil belajar kimia mahasiswa yang memiliki KBK rendah.

3. Tidak terdapat pengaruh yang signifikan interaksi antara penerapan PBL menggunakan animasi maupun peta konsep ditinjau dari KBK mahasiswa terhadap hasil belajar kimia yang dicapai mahasiswa pada materi pokok kelarutan/hasil kali kelarutan.

\section{DAFTAR PUSTAKA}

Akeju., Simpson, O.O., Rotimi, O.C., \& Kenni, M.A. (2012). Teaching With Concept Mapping Instructional Strategy in Nigeria Secondary Schools, Eurasian Journal of Physics and Chemistry Education (EJPCE), (Special Issue):1319.

Asan, A. (2007). Concept mapping in Science Class: A Study of fifth grade students. Jurnal Educational Technology \& Society, 10(1):186-195.

Butar-Butar, R. (2007). Pengaruh Penggunaan Program Animasi Komputer Terhadap Motivasi Dan Hasil Belajar Kimia Siswa SMA Negeri di Kota Sibolga. Tesis tidak diterbitkan. Medan: Program Pascasarjana Unimed.

Dahar, R.W. (2011). Teori-Teori Belajar dan Pembelajaran, Erlangga, Jakarta.

Elvinawati., (2011). Optimalisasi Pembelajaran Kimia Pemisahan Melalui Penerapan Pendekatan Konstruktivisme Dan Model Peta Konsep, Jurnal Exacta, IX(1):23-28.

Hasrul., (2011). Desain Media Pembelajaran Animasi Berbasis Adobe Flash CS3 Pada Mata Kuliah Instalasi Listrik 2, Jurnal Medtek, 3(2):

Hayaton., (2014). Penerapan Model

Pembelajaran Peta Konsep Untuk Meningkatkan Hasil Belajar Materi Proklamasi Kemerdekaan Pada Siswa Kelas VIII SMPN 1 Darul Kamal Tahun Pelajaran 2013/2014, Jurnal Pendidikan Serambi Ilmu, 17(2):84-91.

Iriani, R., Suharto, B., \& Fajar. (2009).

Penggunaan Animasi 3D dalam Pembelajaran Struktur Atom. Ittihad Jurnal Kopertis Wilayah XI Kalimantan, 7(11):59-72.

Jati, B.Y., Mulyani, S., \& Hastuti, B. (2015). Pembelajaran Model Cooperative Integrated Reading And Composition 
(CIRC) Menggunakan Peta Konsep Dan Peta Pikiran Pada Materi Pokok Sistem Koloid Kelas XI Semester Genap SMA N 1 Sragen Tahun Pelajaran 2012/2013, Jurnal Pendidikan Kimia (JPK), 4(1):104112.

Jauhari, M. (2011). Implementasi PAIKEM dari Behavioristik Sampai Konstuktivistik: Sebuah Pengembangan Pembelajaran Berbasis CTL (Contextual Teaching \& Learning), Prestasi Pustakaraya, Jakarta.

Liliasari. (2009). Berpikir Kritis dalam Pembelajaran Sains Kimia Menuju Profesionalitas Guru, http://file.upi.edu/di rektori/sps/prodi.pendidikanipa/19490927 1978032-liliasari /berpikir.kritis.pdf.

Diakses 21 Januari 2016.

Novak, D.J. (2010). Learning, Creating, and Using Knowledge: Concept maps as facilitative tools in schools and corporations, Journal of e-learning and Knowledge Society (Je-LKS), 6(3):21-30.

Riyanto, M. (2010). Paradigma Baru Pembelajaran: Sebagai Refrensi Bagi Pendidik dalam Implementasi Pembelajaran yang Efektif dan Berkualitas, Kencana, Jakarta.

Sakiyo, J., \& Waziri, K. (2015). Concept Mapping Strategy: An Effective Tool for Improving Students' Academic Achievement in Biology, Journal of Education in Science, Environment and Health (JESEH), 1(1):56-62.

Sanjaya, W. (2009). Strategi Belajar Berorientasi Standar Proses Pendidikan, Kencana, Jakarta.

Simatupang, L., \& Dewi, S,R. (2014). Perbaikan Pembelajaran Kuliah Kimia Anorganik Melalui Pengayaan Dan Penggunaan Alat Peraga Pada Pendekatan Pembelajaran Kooperatif Dengan Bantuan Peta Konsep, Jurnal Pendidikan Kimia Pascasarjana Unimed 6(1):19-28.
Syah, M. (2009). Psikologi Belajar, Raja Grafindo Persada, Jakarta.

Trianto., (2011). Mendesain Model Pembelajaran Inovatif-Progresif: Konsep, Landasan, dan Implementasinya Pada Kurikulum Tingkat Satuan Pendidikan (KTSP), Kencana, Jakarta. 